\title{
Evropská směrnice INSPIRE
}

\author{
Pavla Tryhubová \\ Department of Mapping and Cartography \\ Faculty of Civil Engineering, CTU in Prague \\ E-mail: pavla.tryhubova@fsv.cvut.cz
}

\begin{abstract}
Abstrakt
Článek byl vytvořen na základě informací ze semináře a workshopu organizovaného sdružením Nemoforum spolu se Společným výzkumným centrem Evropské komise (EC Joint Research Centre - Ispra, Itálie) a CENIA, českou agenturou pro životní prostředí. Tématem semináře a workshopu byla Geoinformační infrastruktura C̆R a INSPIRE.

Česká republika vstoupila do Evropské unie (EU) spolu s dalšími devíti státy 1. května 2004. Změny na trhu s geodaty uvnitř Evropské unie se dotýkaji $i$ České republiky. Hlavním ohniskem těchto změn je iniciativa INSPIRE. INSPIRE by se měla stát evropskou směrnicí v roce 200\%. INSPIRE podporuje harmonizaci prostorových formátu dat, dostupnost datových sad a schopnost vyhledat rüzné datové sady. V první části článku je shrnut poslední vývoj uvnitr iniciativy INSPIRE a v druhé části jsou zveřejněny závěry zmiňovaného semináre a workshopu.
\end{abstract}

\section{Obecně o INSPIRE}

INSPIRE byl založen na souboru základních pravidel:

- data by měla být sbírána jednou a držena na té úrovně kde je sbírání dat nejúčinnějšś;

- mělo by být možné propojit prostorové informace z různých evropských zdrojů a mezi mnoho uživatelů a aplikací;

- mělo by být možné pro informace sebrané na jedné úrovni sdílení do všech ostatních úrovní;

- na všech úrovních by mělo být dostatečné množství geodat a za podmínek, které umožní jejich rozsáhlé použití;

- mělo by být snadné najít, která geodata jsou dostupná, která se hodí pro zvláštní použití a za kterých podmínek je mohu získat a používat;

- geodata by se měla stát snadno pochopitelná a interpretovatelná

INSPIRE je návrhem (COM (2004) 516 finale, 23/7/2004) Evropské komise na směrnici pro založení infrastruktury pro prostorové informace v EU, která podporuje dostupnost, a př́stup $\mathrm{k}$ prostorovým informacím. [1] Iniciativa chce zajistit vytvoření evropské prostorové informační infrastruktury, která zpřístupní uživatelům integrované prostorové informační služby. Tyto služby by měly dovolit uživatelům najít a zpřístupnit prostorové nebo geografické 
informace z pestré škály zdrojů, od místní úrovně ke globální úrovni, interooperabilitní cestou pro celou řadu použití. Uživatelské cíle INSPIRE zahrnují politiky, plánovače a evropské manažery, na národní a místní úrovni a občany a organizace. [2]

Prostorová data hrají důležitou roli při rozhodování vlády, organizací i jednotlivců. Vlády potřebují plánovat politiku pro zemědělství, průmysl, oblastní růst, dopravu a bezpečnost a pak potřebují sledovat postup své strategie a vidět zda nastávají žádoucí výsledky. Mít zmapovanou zemi je důležité pro efektivní vývoj tržního hospodářství. Podobné příklady existují i na evropské úrovni, zvlášt když uvážíme požadavky evropské komise pro politiku plánování a rozhodovací strategie, například navržení dopravní sítě nebo sledovaní znečištění životního prostředí. Zvládat tyto procesy na evropské úrovni by nebylo možné bez nějaké úrovně harmonizace. Každá země má pro své mapy jiná měřítka, jiné souřadnicové systémy, jiná zobrazení, některé země mají zatím analogové mapy některé mají digitální, každá země má jiné formáty dat, atd. Evropská komise chce dát právní rámec pro vytvoření a fungování prostorové geoinformační infrastruktury. INSPIRE se zpočátku zaměřil na potřeby environmentální politiky ale postupně se rozšiřuje i do jiných sektorů (např. zemědělství, doprava). INSPIRE zamýšlí vytvořit infrastrukturu uvnitř Evropy, která umožní větší přístup $\mathrm{k}$ datům a $\mathrm{k}$ použíání prostorových dat. Pak by mělo být snadnější najít, která data existují, a každá země bude mít jisté minimální typy dat, ke kterým by uživatelé měli být schopni přistupovat a připojit si požadovanou zájmovou oblast.

Cílem INSPIRE, je odpovědět na všechny sporné otázky - bude existovat jeden webový portál kde najdete data, která existují. Jestliže momentálně tyto data neexistují, členské státy EU budou muset takové datové sady vytvořit. Datové sady budou vyhovovat standardů, které musí zajistit možnost spojení s daty z jiných zemí a z různých měřítek. Výhody pro evropskou komisi jsou zřejmé, ale jsou tu také nesporné výhody pro běžného občana. Pokud stát dovolí větší používání prostorových dat, otevře tak cestu pro tisíce nových žádostí - například díky internetu, by občan mohl kontrolovat využití územního plánování, zapsání vlastnictví nebo nalezení nejbližší banky s použitím mobilního telefonu. Směrnice INSPIRE uvádí požadavky pro tuto infrastrukturu a až se stane realitou, pak tyto požadavky budou předloženy národní legislativě. Proces, který bude trvat několik let, bude řízený evropskou komisí, ale bude harmonizován s pomocí národních oborových organizací pro přípravu a usnadnění cílů INSPIRE.

\section{Aktuální stav směrnice}

Návrh byl vytvářen několik let a je výsledkem práce geoinformačních expertů ze všech členských států. Směrnice je nyní prochází fází spolurozhodovacího procesu. [3] Parlament a Rada ES nedosáhli "prvního čtenî" dohody v červenci 2005, ale na zasedání Rady pro zemědělství a rybářské oblasti, které se konalo v Bruselu 23.ledna 2006 byl přijat společný postoj rady ES a směrnice byla představena na plenární schůzi v únoru 2006. Parlament má ted’ 3 měsíce (plus jeden v případě druhého čtení dohody v radě ES) pro vyjádření ke sporným otázkám. To by znamenalo na květnové nebo červnové schůzi, s diskuzí v (parlamentním výboru) v březnu nebo dubnu.

Směrnice INSPIRE by mohla vstoupit v platnost na začátku roku 2007. Zároveň jako spolurozhodující proces se koná příprava dohodnutého Pracovního programu pro zahájení prácí před přijetím směrnice. Práce závisí na práci malé základní skupiny v Evropské komisi a na 
počtu dobrovolných expertů z řad členských států. Tito experti vytvoří sadu implementačních pravidel pro hlavní oblasti iniciativy. Od počátečního návrhu z července 2004 k úplně realizaci směrnice projde INSPIRE třemi fázemi.

Směrnice INSPIRE se rozvíjí a bude realizována v každém členském státu EU, Česká republika, jako všechny členské státy, bude nucena implementovat řadu akcí. [4]

\section{Přípravná fáze (2005-2006)}

V tomto stádiu se právě nacházíme. Jak už bylo řečeno INSPIRE nyní prochází spolurozhodující procedurou, Evropská komise spolupracuje s radou a Evropským parlamentem při vytvoření konečného tvaru směrnice. Trvání spolurozhodující procedury je odhadováno na dva roky a po schválení se z návrhu INSPIRE stane směrnice evropského společenství.

INSPIRE bude vyžadovat, aby členské státy realizovaly množství opatření. Česká republika jako členský stát, si musí být vědoma nastávajících závazků a musí rozumět hlediskům zdrojů, časovým rámcům, a spojení na aktuální vývoj NSDI. Č́st opatření vyžadovaných směrnicí musí být realizováno přímo v členských státech, zatímco jiná vyžadují více detailů, popsaných v "Implementačních pravidlech" (Implementing Rules). V nařízeních pro členské státy je část o tom, že členské státy musí být schopny přizpůsobit se časovému plánu realizace INSPIRE, implementační pravidla musí být samozřejmě dostupná ve správný čas. Nyní je připraveno pět skupin dobrovolníků z členských států pod vedením konsolidačního týmu z JRcentra.

Skupiny:

- Skupina pro návrh metadat

- Skupina pro specifikace dat

- Skupina pro sítové-internetové služby

- Skupina pro sdílení dat a služeb

- Skupina pro monitoring a zpravodajství

Implementační pravidla budou posuzována komunitou zajímající se o prostorová data (Spatial Data Interest Communities - SDIC) a projdou iteračním procesem předtím, než budou dány organizací pověřenou řídit SDI aktivity (Legally Mandated Organisations - LMOs), kde budou ověřena pravidla a okomentován dopad a proveditelnost návrhů. Návrhy pak půjdou do veřejného projednávání, aby zahrnovaly všechny možné investory v př́pravné fázi. Členské státy chtějí hlasovat o finální verzi implementačních pravidel na dalším výboru INSPIRE.

\section{Fáze transpoziční (2007-2008)}

Po přijetí INSPIRE jako směrnice společenství, členské státy mají období dvou let na přenesení INSPIRE do jejich národní legislativy.

V této chvíli musí mít organizace $\mathrm{v}$ členských státech kontakt na Evropskou komisi, je nutné zajistit koordinaci na úrovni evropského společenství, který také zahrnuje kontakt $\mathrm{s}$ 
komisí. Implementační pravidla, a vytvořené dobrovolnické skupiny budou vypracovávat podrobná opatření, které mají být přijata členskými státy, nebo v některých případech Komisí. Během transpoziční fáze bude zapotřebí přijmout implementační pravidla členskými státy dle časového plánu směrnice INSPIRE. Regulační charakter Implementačních pravidel vyžaduje, aby je Komise předala INSPIRE výboru zástupců členských států, který oficiálně začne s aktivitami na začátku transpoziční fáze (Během tří měsíců od vstoupení v platnost). INSPIRE výbor má jako hlavní úkol pomáhat Komisi a předávat názory na návrh realizace Implementačních pravidel navrhovaných Komisí. Tyto názory se musí odhlasovat. V př́ípadě INSPIRE, Komise může přijmout Implementační pravidla, jestliže je většina členských států odsouhlasí. Jestliže je neodsouhlasí, Komise předloží navrhované Implementační pravidla Evropské Radě a informuje Evropský parlament. Vůle rady pak může změnit nepřijetí hlasováním většiny, jestliže se postaví proti návrhu, poveř̌ení lidé musí přezkoušet a podat doplněný návrh. Jakmile budou implementační pravidla přijata, členské státy musí zajistit jejich aplikaci podle časového plánu INSPIRE.

\section{Fáze realizace $(2009-2013)$}

Až bude INSPIRE transponován členskými státy do národní legislativy, jeho požadavky budou realizovány a bude sledováno dodržování časového plánu INSPIRE. Koordinace na úrovni Evropského Společenství a na úrovni členských státu bude operační a zpravodajská - zprávy o stavu implementace INSPIRE a dodržování členskými státy musí být podle časového plánu INSPIRE.

\section{Předpokládaný časový plán}

Tabulka shrnuje milníky INSPIRE tak jak je vydal ESTATJRC. [6] Milníky jsou založené na přijetí INSPIRE jako směrnice v 2007, samozřejmě existuje riziko, že tyto milníky nebudou dodrženy:

\begin{tabular}{|l|c|}
\hline Popis & Datum \\
\hline \hline Založení výboru INSPIRE (během 3 měsíců od vstoupení v účinnost) & 2007 \\
\hline $\begin{array}{l}\text { Přijetí implementačních pravidel pro vytvoření a aktualizaci metadat } \\
\text { Přijetí implementačních pravidel pro sítové služby }\end{array}$ & 2007 \\
$\begin{array}{l}\text { Přijetí implementačních pravidel pro užívání služeb třetími osobami } \\
\text { Přijetí implementačních pravidel pro monitoring }\end{array}$ & \\
$\begin{array}{l}\text { Přijetí implementačních pravidel pro přístup a práva pro používání prosto- } \\
\text { rových souboru dat a služeb pro instituce Evropského společenství }\end{array}$ & \\
\hline Zpráva o přijetí implementačních pravidel & 2008 \\
\hline $\begin{array}{l}\text { Přijetí implementačních pravidel pro užívání prostorových datových sou- } \\
\text { borů a služeb třetími osobami }\end{array}$ & 2009 \\
\hline $\begin{array}{l}\text { Přijetí implementačních pravidel pro sladění specifikace prostorových dat } \\
\text { z přílohy I. a výměnu dat z př́lohy I, II a III }\end{array}$ & 2009 \\
\hline $\begin{array}{l}\text { Určení zodpovědnosti veřejných úřadů pro prostorové datové soubory a } \\
\text { služby }\end{array}$ & 2009 \\
\hline
\end{tabular}




\begin{tabular}{|l|c|}
\hline $\begin{array}{l}\text { Implementace rámce prostorových datových souborů a služeb veřejnými } \\
\text { institucemi }\end{array}$ & 2009 \\
\hline Realizace sledování implementačních pravidel & 2009 \\
\hline $\begin{array}{l}\text { Metadata dostupná pro prostorová data odpovídající Příloze I. a Př́lloze } \\
\text { II. prostorová data }\end{array}$ & 2010 \\
\hline Sítové služby & 2010 \\
\hline První zpráva členských států komisi EU & 2011 \\
\hline $\begin{array}{l}\text { Nové nebo aktualizované prostorové datové sady se stanou dostupné dle } \\
\text { implementačních pravidel pro sladění specifikace a výměny prostorových } \\
\text { dat z Př́lohy I. prostorová data }\end{array}$ & 2011 \\
\hline $\begin{array}{l}\text { Přijetí implenačních pravidel pro sladění specifikace prostorových dat z } \\
\text { Př́lohy II a Př́lohy III prostorová data }\end{array}$ & 2011 \\
\hline Dostupná metadata z Př́lohy III prostorová data & 2013 \\
\hline $\begin{array}{l}\text { Nové nebo aktualizované prostorové datové sady se stanou dostupné dle } \\
\text { implementačních pravidel pro sladění specifikace a výměny prostorových } \\
\text { dat z Př́lohy II. A Přílohy III. prostorová data }\end{array}$ & 2013 \\
\hline Druhá zpráva členských států komisi EU & 2013 \\
\hline
\end{tabular}

\section{Seminář a workshop "Geoinformační infrastruktura v ČR a INSPIRE"}

Jaké je v České republice povědomí o směrnici INSPIRE ukázal seminář a workshop věnovaný vzájemným vazbám mezi existující geoinformační infrastrukturou v České republice a záměry připravované evropské směrnice INSPIRE. Seminář a workshop se uskutečnil 14.3 a 15.3. 2006 v konferenčním sálu ČÚZK v Kobylisích.

Vysoká účast na semináři, kde bylo široké spektrum organizací zastoupeno přímo vedoucími pracovníky, potvrzuje zájem o vývoj INSPIRE. Semináře se zúčastnilo 100 účastníků a workshopu 48 účastníků. Zastoupena byla jednak veřejná správa představiteli z ministerstev; dále zástupci krajů; lidé z úřadů; posluchači a učitelé z vysokých škol ale i soukromé firmy.

Přednášející byli osloveni sdružením Nemoforum a JRC dodalo osnovu přednášky s předpřipravenými otázkami ohledně INSPIRE a vztahům INSPIRE k organizaci přednášejícího. Všichni účastnící dostali ve svých materiálech k semináři papírový dotazník rovněž s připraveným dotazníkem a otázkami k INSPIRE. Přednášky a závěry s dotazníky byly zpracovány a závěry zveřejněny na stránkách Nemofora. [7]

Je zřejmé, že tématicky nebo územně vymezené geoinformační infrastruktury jsou chápany jako součást širšího národního a evropského kontextu. Směrnice INSPIRE je považována za horizontální rámec, který umožní vybudování národní prostorové informační infrastruktury v rozsahu překračujícím stávající kompetenční aj. bariéry mezi jednotlivými resorty a institucemi.

Řada z prezentovaných př́kladů na národní i regionální úrovni již nyní odpovídá principům INSPIRE. 


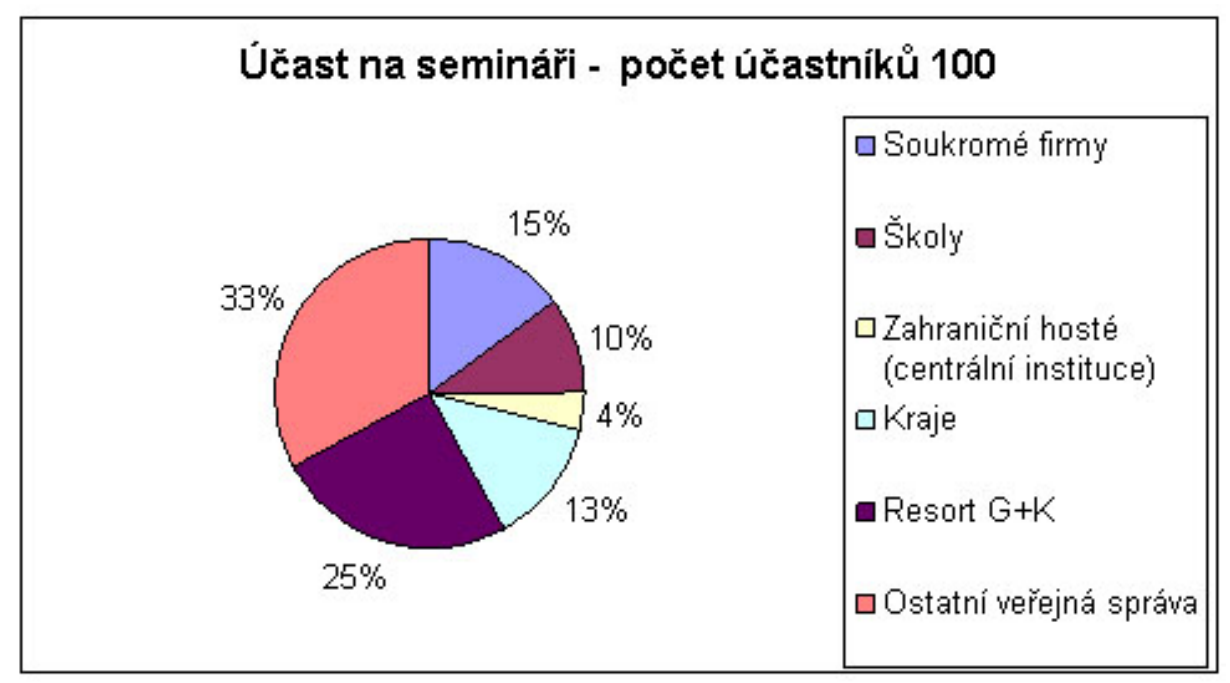

Obrázek 1: Účast na semináři

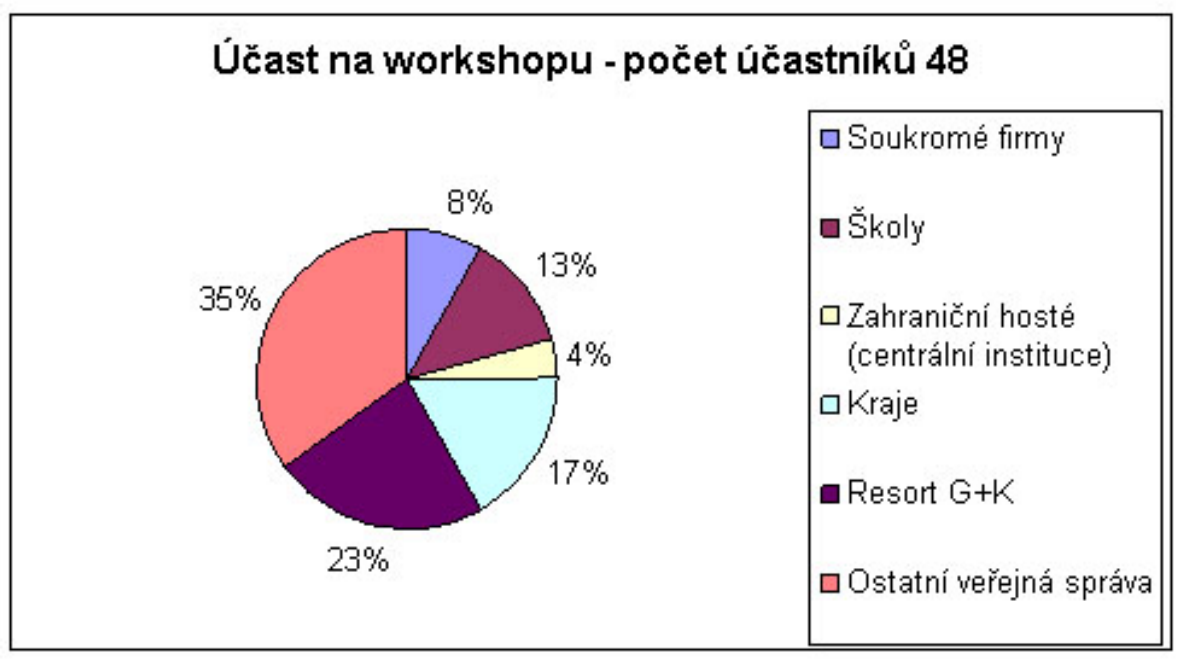

Obrázek 2: Účast na workshopu

Projeveny zájem o aktivní zapojení do příprav INSPIRE je možný uspokojit po třech liniích:

- Zapojením do procesu tvorby technických prováděcích předpisů INSPIRE, který je koordinován EC JRC.

- Cestou vytvoření a registrace nových SDIC a LMO nebo přidružením k takto již zaregistrovaným organizacím (připomínkováním, testováním návrhů, účastí v průzkumu připravenosti v oblasti metadat); viz www.inspire-jrc.it

- Zapojením do procesu př́íprav implementace směrnice INSPIRE v ČR.

Česká informační agentura pro životní prostředí (CENIA) předložila k diskusi rámcový implementační plán a dolad'uje návrh umožňující informované zapojení zainteresovaných institucí a organizací do procesu příprav. 


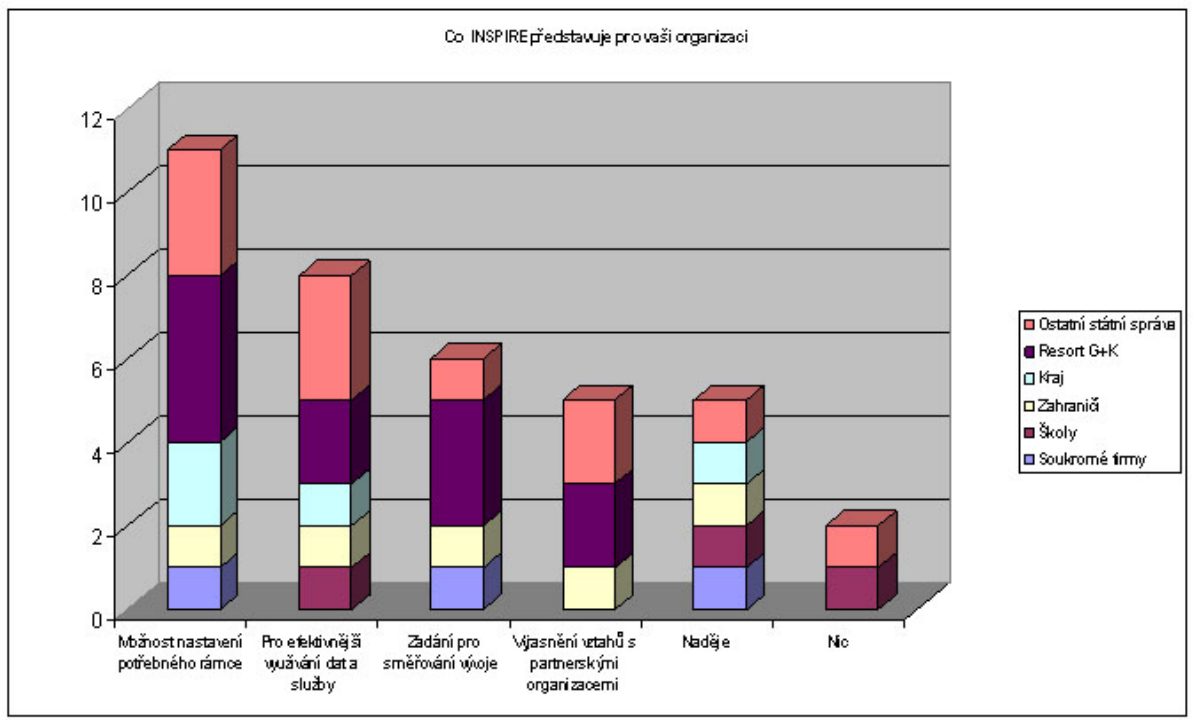

Obrázek 3: Graf byl vyhotoven z papírových dotazníků

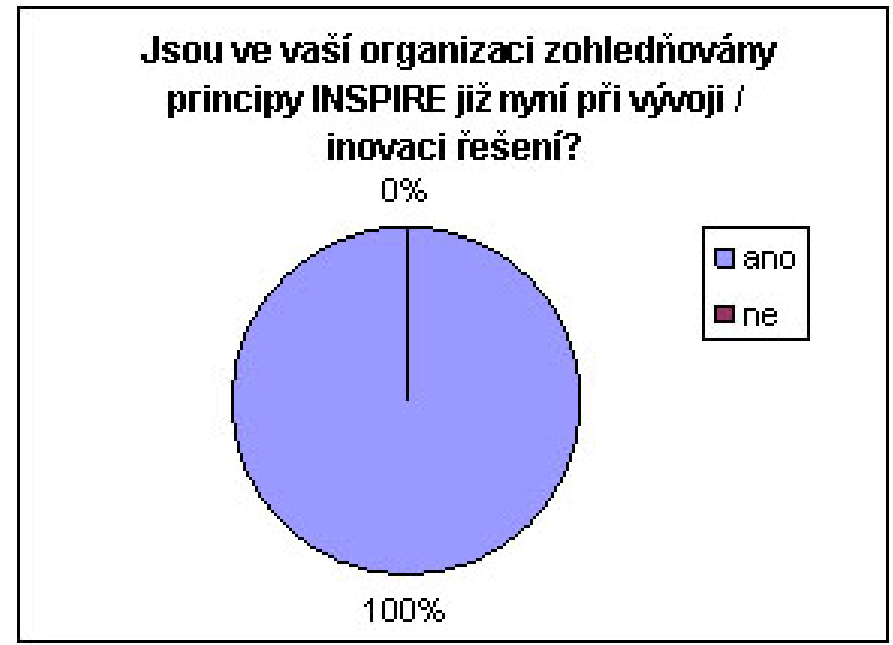

Obrázek 4: Graf byl vyhotoven z prezentací přednášejících

Návrh obsahuje zřízení předimplementační skupiny, implementačního výboru a navrhuje zahájení vyjednání. MŽP a MI oficiálně přizvou další ústř̌ední orgány a zástupce krajů k účasti na vyjednávání směrnice. MŽP vstoupí do Nemofóra, které se tak stane primární diskusní platformou INSPIRE.

Předimplementační skupina bude formálně ustanovena ze zástupců ústředních orgánů, krajů, obcí a profesních sdružení pod vedením MŽP (účel), MI (nadresortnost) a ČÚZK (hlavní poskytovatel).

Výstupem předimplementační skupiny bude návrh pro vládu ČR:

- Identifikace hlavních hráčů (stakeholders)

- Definice strategických cílů 
- Rozvoj současných aktivit

- Datová politika ČR

- Legislativní implementace

- Komunikační a diseminační politika INSPIRE

- Definice organizace implementace INSPIRE

- Dokumenty budou veřejně projednávány

Implementační výbor zajistí provedení a bude sledovat průběh a dávat zpětnou vazbu pro kontinuální zlepšování. Ve vazbě na vývoj v EU a zájmy ČR bude dávat podněty vládě ČR k úpravám a doplnění návrhu.

\section{Závěr}

Výsledky a zkušenosti, které vzešly díky pilotnímu českému semináři a workshopu, poslouží jako kvalitní a transparentní základ pro přípravu dalších osvětových akcí v nových členských státech EU a přistupujících zemích.

Z odpovědí na dotazník i debaty vyplynulo množství návrhu, ze strany JRC a CENIA, jak zlepšit informační služby zaměřené na INSPIRE a jak posílit osvětu (JRC, CENIA spolu s profesními organizacemi, vysokými školami).

Náměty pro informační služby:

- mohutnější propagace ve veřejné správě - koncepční semináře, přednášky na konferencích, osvětové letáčky, účasti v různých projektech (Nature regine, projekt modernizace ústřední správy)

- zřízení diskusního fóra na Internetu, zapojení internetových serverů města a obce online, a dalších.

\section{Literatura}

1. http://inspire.jrc.it/

2. http://www.ec-gis.org/inspire

3. http://europa.eu.int/comm/codecision/stepbystep/text/index_en.htm

4. http://inspire.jrc.it/sdic_call/rhd040705WP4A_v4.5.3_final-2.pdf

5. Council Decision (1999/468/EC) Official Journal L 184/23, 17.7.1999, "laying down the procedures for the exercise of implementing powers conferred on the Commission".

6. Working Programme Preparatory Phase http://inspire.jrc.it/sdic_call/rhd040705WP4A_v4.5.3_final.pdf

7. http://www.cuzk.cz/nemoforum 